\title{
PENGARUH PEMBERIAN JUS APEL FUJI (MALUS DOMESTICA) DAN SUSU TINGGI KALSIUM RENDAH LEMAK TERHADAP KADAR KOLESTEROL HDL DAN LDL PADA TIKUS SPRAGUE DAWLEY HIPERKOLESTEROLEMIA
}

\author{
Okka Roza Linda Irawati, Muhammad Sulchan") \\ Program Studi Ilmu Gizi Fakultas Kedokteran Universitas Diponegoro \\ Jl.Dr.Sutomo No.18, Semarang, Telp (024) 8453708, Email : gizifk@ undip.ac.id
}

\begin{abstract}
Background : Hypercholesterolemic is one cardiovascular disease risk factor. signed by highness total cholesterol level in the blood. Apple and high calcium low fat milk may be beneficial for decreasing LDL and increasing cholesterol level in the blood. This study aims to get the information on the effect of fuji apple juice and highcalcium low fat milk on total cholesterol level in hypercholesterolemic Sprague Dawley rats

Methods: This study is a true experimental study with pre-post test randomized control group design that used 30 Sprague-Dawley rats. Groupings were randomly divided into 6 groups. There were negative control group that were only given standard feed, positive control group that were given standard and high cholesterol feed. Two groups were given standard feed, high cholesterol feed and fuji apple juice with or without peels. The rest of groups were given standard feed, high cholesterol feed, high calcium low fat milk and juice fuji apple with or without peels for 14 days. Data were analyzed by Paired t-test / Wilcoxon and One Way Anova / Kruskall Wallis

Results: LDL level in $K$ - group increase from $24 \mathrm{mg} / \mathrm{dl}$ to $27.8 \mathrm{mg} / \mathrm{dl}$ and $\mathrm{K}+$ group increase from $19.5 \mathrm{mg} / \mathrm{dl}$ to $22 \mathrm{mg} / \mathrm{dl}$. LDL cholesterol level in P1 group decrease from $27 \mathrm{mg} / \mathrm{dl}$ to $25.8 \mathrm{mg} / \mathrm{dl}$, P3 group decrease from 24.4 $\mathrm{mg} / \mathrm{dl}$ to $20.8 \mathrm{mg} / \mathrm{dl}$, P2 group increase from $25 \mathrm{mg} / \mathrm{dl} \mathrm{to} 30.8 \mathrm{mg} / \mathrm{dl}$ and P4 group increase from $22.8 \mathrm{mg} / \mathrm{dl}$ to $24.8 \mathrm{mg} / \mathrm{dl}$. HDL level in $\mathrm{K}$ - group increase from $19.2 \mathrm{mg} / \mathrm{dl}$ to $20 \mathrm{mg} / \mathrm{dl}$ and $\mathrm{K}+$ group decrease from $17.7 \mathrm{mg} / \mathrm{dl}$ to $15.5 \mathrm{mg} / \mathrm{dl}$. HDL cholesterol level in P1 group decrease from $19 \mathrm{mg} / \mathrm{dl}$ to $18 \mathrm{mg} / \mathrm{dl}$, P2 group decrease from $21.7 \mathrm{mg} / \mathrm{dl}$ to $17.5 \mathrm{mg} / \mathrm{dl}$, P3 group decrease from $18.6 \mathrm{mg} / \mathrm{dl}$ to $16.8 \mathrm{mg} / \mathrm{dl}$. Therre was no change in $\mathrm{P} 4$ group $18 \mathrm{mg} / \mathrm{dl}$. Based on ANOVA test there was no significant difference was observed regarding LDL cholesterol and $H D L$ cholesterol level between all groups $(p=0.224)$ and $(p=0.279)$

Conclusion: Giving unpeeled apple juice, peeled apple juice, unpeeled apple juice with high calcium low fat milk and peeled apple juice with high calcium low fat for 14 days had no effect on LDL cholesterol level and HDL cholesterol level in hypercholesterolemic rats.
\end{abstract}

Keyword : Fuji apple juice; high calcium low fat milk; quercetin; pectin; calcium; HDL cholesterol; LDL cholesterol

\begin{abstract}
ABSTRAK
Latar Belakang : Hiperkolesterolemia merupakan salah satu faktor risiko penyakit kardiovaskuler yang ditandai dengan peningkatan kadar kolesterol darah diatas batas normal. Apel dan susu tinggi kalsium rendah lemak bermanfaat untuk meningkatkan kadar kolesterol HDL dan menurunkan kadar kolesterol LDL dalam darah. Penelitian ini bertujuan untuk mengetahui pengaruh jus apel dan susu tinggi kalsium rendah lemak terhadap kadar kolesterol HDL dan LDL dalam darah pada tikus Sprague Dawley hiperkolesterolemia

Metode: Penelitian ini merupakan penelitian true experimental dengan pre-post test randomized control group design yang menggunakan 30 ekor tikus Sprague Dawley. Pengelompokan dilakukan secara acak menjadi 6 kelompok yaitu kelompok kontrol negatif yang hanya diberikan pakan standar, kontrol positif yang diberikan pakan standar dan tinggi kolesterol. Dua kelompok diberikan pakan standar, pakan tinggi kolesterol dan jus apel fuji dengan kulit dan jus apel fuji tanpa kulit. Dua kelompok lainnya mendapat pakan standar, pakan tinggi kolesterol, susu tinggi kalsium rendah lemak dan jus apel fuji dengan kulit dan tanpa kulit selama 14 hari. Data dianalisis dengan uji Paired t-test/ Wilcoxon dan Anova/ Kruskall Wallis.

Hasil: Kadar kolesterol LDL darah pada kelompok K-naik dari 24 mg/dl menjadi 27,8mg/dl, kelompok K+ naik dari 19,5mg/dl menjadi 22mg/dl.Kadar kolesterol LDL darah pada kelompok P1 turun dari 27mg/dl menjadi 25,8mg/dl, kelompok P3 turun dari 24,4mg/dl menjadi 20,8mg/dl, kelompok P2 naik dari 25mg/dl menjadi 30,8mg/dl dan kelompok P4 naik dari 22,8mg/dl menjadi 24,8mg/dl. Kadar kolesterol HDL darah pada kelompok $\mathrm{K}$ - naik dari 19,2mg/dl menjadi 20mg/dl dan kelompok K+ turun dari 17,7mg/dl menjadi 15,5mg/dl.Kadar kolesterol HDL darah pada kelompok P1 turun dari 19mg/dl menjadi $18 \mathrm{mg} / \mathrm{dl}$, kelompok P2 turun dari 21,7mg/dl menjadi 17,5mg/dl, kelompok P3 turun dari 18,6mg/dl menjadi 16,8mg/dl dan kelompok P4 tetap $18 \mathrm{mg} / \mathrm{dl}$. Tidak ada perbedaan perubahan kadar kolesterol LDL dan HDL antar kelompok secara berurutan yaitu $(p=0,224)$ dan $(p=0,279)$
\end{abstract}


Simpulan: Pemberian jus apel dengan kulit, jus apel, jus apel dengan kulit dengan susu tinggi kalsium rendah lemak serta jus apel dengan susu tinggi kalsium rendah lemak selama 14 hari tidak berpengaruh terhadap kadar kolesterol LDL dan kolesterol HDL darah pada tikus hiperkolesterolemia .

Kata kunci : Jus apel fuji; susu tinggi kalsium rendah lemak; quercetin; pektin; kalsium; kolesterol HDL; kolesterol $L D L$

\section{PENDAHULUAN}

Penyakit kardiovaskuler merupakan salah satu penyebab kematian terbesar di dunia, data WHO 2008 memperkirakan 17,3 juta orang meninggal karena penyakit kardiovaskuler. ${ }^{1}$ Salah satu faktor risiko utama penyakit kardiovaskuler adalah dislipidemia.

Hiperkolesterolemia adalah salah satu gangguan kadar lemak dalam darah (dislipidemia) yang ditandai kadar kolesterol dalam darah lebih dari $240 \mathrm{mg} / \mathrm{dl} .^{2}$ Hiperkolesterolemia berhubungan erat dengan kadar kolesterol LDL di dalam darah.Diet rendah lemak jenuh dan kolesterol, olahraga secara teratur, pengendalian berat badan serta terapi farmakologi merupakan cara yang tepat dalam menurunkan kadar kolesterol LDL serta meningkatkan kadar kolesterol HDL.Modifikasi diet yang dapat dilakukan untuk menurunkan kadar kolesterol dan pengendalian berat badan antara lain mengonsumsi makanan rendah lemak, meningkatkan asupan sayur dan buah yang kaya serat dan antioksidan serta mengonsumsi sumber makanan tinggi kalsium seperti apel dan susu.

Apel Fuji (Malus domestica) merupakan buah yang banyak mengandung antioksidan terutama quercetin, catechin, phloridzin dan asam klorogenik. Apel fuji dipilih karena kandungan antioksidannya tertinggi yaitu $108 \mathrm{mg}$ catechin equivalents $/ 100 \mathrm{~g}$ apel,selain mengandung antioksidan terdapat kandungan pektin pada kulit apel. ${ }^{3}$ Pektin termasuk jenis serat pangan yang larut air dan mudah difermentasi oleh mikroflora usus besar. ${ }^{4}$ Di dalam saluran pencernaan, serat larut air mengikat asam empedu yang merupakan produk akhir dari kolesterol dan kemudian dikeluarkan bersama feses. Hal tersebut yang diduga dapat menyebabkan terjadinya penurunan kadar kolesterol di dalam tubuh. ${ }^{5}$ Penelitian mengenai pemanfaatan apel terhadap perubahan profil lipid kelinci dengan dosis $10 \mathrm{ml}$ jus apel selama 2 bulan pernah dilakukan. Hasilnya menunjukan bahwa jus apel mampu menaikkan kadar kolesterol HDL secara signifikan dari 25,67 $\mathrm{mg} / \mathrm{dl}$ menjadi $108,83 \mathrm{mg} / \mathrm{dl}^{6}{ }^{6}$

Penelitian yang pernah dilakukan menunjukkan bahwa susu kaya akan kalsium lebih mudah diserap tubuh. Diet kalsium dapat mengurangi intraseluler $\mathrm{Ca}$, menurunkan lipogenesis dan meningkatkan lipolisis ${ }^{7,8}$ Diet kalsium juga meningkatkan ekskresi lemak. ${ }^{9}$

Berdasarkan latar belakang tersebut, maka perlu dikaji kembali pengaruh pemberian jus apel fuji dan susu terhadap kadar kolesterol HDL dan kolesterol LDL tikus Sprague dawley hiperkolesterolemia. Tikus dipilih sebagai subjek dalam penelitian ini karena memiliki sifat lebih tahan terhadap perlakuan, mudah beradaptasi dalam kondisi laboratorium, serta kemiripan karakteristik imunologis dan anatomi organ dengan manusia sehingga peka terhadap pengaruh pemberian kolesterol dalam diet. Selain itu juga dapat dilakukan kontrol dari segi asupan makanan untuk menghindari adanya bias pada hasil penelitian.

\section{METODE PENELITIAN}

Penelitian yang dilakukan di Laboratorium Parasitologi Fakultas Kedokteran Universitas Diponegoro ini merupakan penelitian experimental laboratorik dengan pre-post test randomized control group design. ${ }^{10}$ Variabel bebas pada penelitian ini adalah pemberian jus apel fuji dengan atau tanpa kulit dan susu tinggi kalsium rendah lemak sedangkan variabel terikat dalam penelitian ini adalah kadar kolesterol HDL dan LDL

Sampel penelitian yang digunakan adalah tikus jantan galur Sprague Dawley umur 8 minggu dengan berat badan rata-rata 150- 200 gram yang diperoleh dari Laboratorium Farmasi Universitas Gadjah Mada, Yogyakarta. Besar sampel minimal dalam penelitian ini ditentukan berdasarkan rumus Federer. ${ }^{10}$ Penelitian ini menggunakan 4 ekor tikus untuk setiap kelompok perlakuan untuk mengantisipasi terjadinya drop out, sehingga jumlah tikus yang digunakan adalah 30 ekor dibagi menjadi 6 kelompok.Kelompok pada penelitian ini terdiri dari kontrol negatif, kontrol positif, kelompok perlakuan dosis 4,62g jus apel fuji dengan kulit, kelompok perlakuan dosis $4,62 \mathrm{~g}$ jus apel fuji tanpa kulit, kelompok perlakuan dosis $4,62 \mathrm{~g}$ jus apel fuji dengan kulit diambah dosis $6,16 \mathrm{ml}$ susu tinggi kalsium rendah lemak dan kelompok perlakuan dosis 4,6g jus apel fuji tanpa kulit ditambah dosis $6,16 \mathrm{ml}$ susu tinggi kalsium rendah lemak. Jus apel dan susu diberikan 
menggunakan sonde dengan frekuensi jus apel 1 kali dan susu 2 kali dalam sehari.

Seluruh sampel diadaptasi terlebih dahulu selama 7 hari dengan menggunakan pakan standar BR-2 sebanyak 20 gram/ekor/hari dan minum ad libitum. Selanjutnya, sampel dibagi menjadi 6 kelompok secara acak. Kelompok kontrol negatif diberikan pakan standar sampai akhir penelitian, kelompok kontrol positif dan kelompok perlakuan diberi pakan standar serta pakan tinggi kolesterol selama 14 hari untuk membuat tikus menjadi hiperkolesterolemia. Sebelum memasuki tahap intervensi dilakukan pengambilan darah awal.

Pakan tinggi kolesterol berupa otak sapi yang telah dikukus lalu diblender dan diberikan melalui sonde sebanyak $10 \%$ dari pakan standar atau $2 \mathrm{ml} / \mathrm{ekor} / \mathrm{hari} .{ }^{11} \mathrm{Jus}$ apel yang diberikan berasal dari apel fuji yang dihaluskan menggunakan blender, kemudian ditimbang sebanyak 4,62 mg, setelah itu disaring dan diberikan melalui sonde. Ampas kulit apel diberikan pada kelompok perlakuan jus apel fuji dengan kulit. Ampas apel diberikan bersama pakan standard tikus, sedangkan susu dengan dosis $6,16 \mathrm{ml}$ diberikan 2 kali penyajian melalui alat sonde.

Pengambilan darah sampel sebelum intervensi dimaksudkan untuk melihat kadar kolesterol HDL dan LDL setelah pemberian pakan tinggi kolesterol selama 14 hari. Pengambilan sampel darah akhir untuk melihat kadar kolesterol HDL dan LDL setelah pemberian jus apel fuji dengan atau tanpa kulit dan susu tinggi kalsium rendah lemak selama 14 hari. Sampel darah diambil sebanyak $2 \mathrm{ml}$ melalui pleksus retroorbitalis. ${ }^{12}$ Data yang diperoleh diolah dengan program komputer. Data tersebut diuji normalitasnya dengan uji Saphiro Wilk. Perbedaan kolesterol HDL dan LDL sebelum dan sesudah perlakuan menggunakan uji statistik parametrik Paired t-test (normal) . Perbedaan pengaruh dosis dari keenam kelompok perlakuan dianalisis menggunakan uji statistik parametrik One Way Anova (normal). ${ }^{13}$

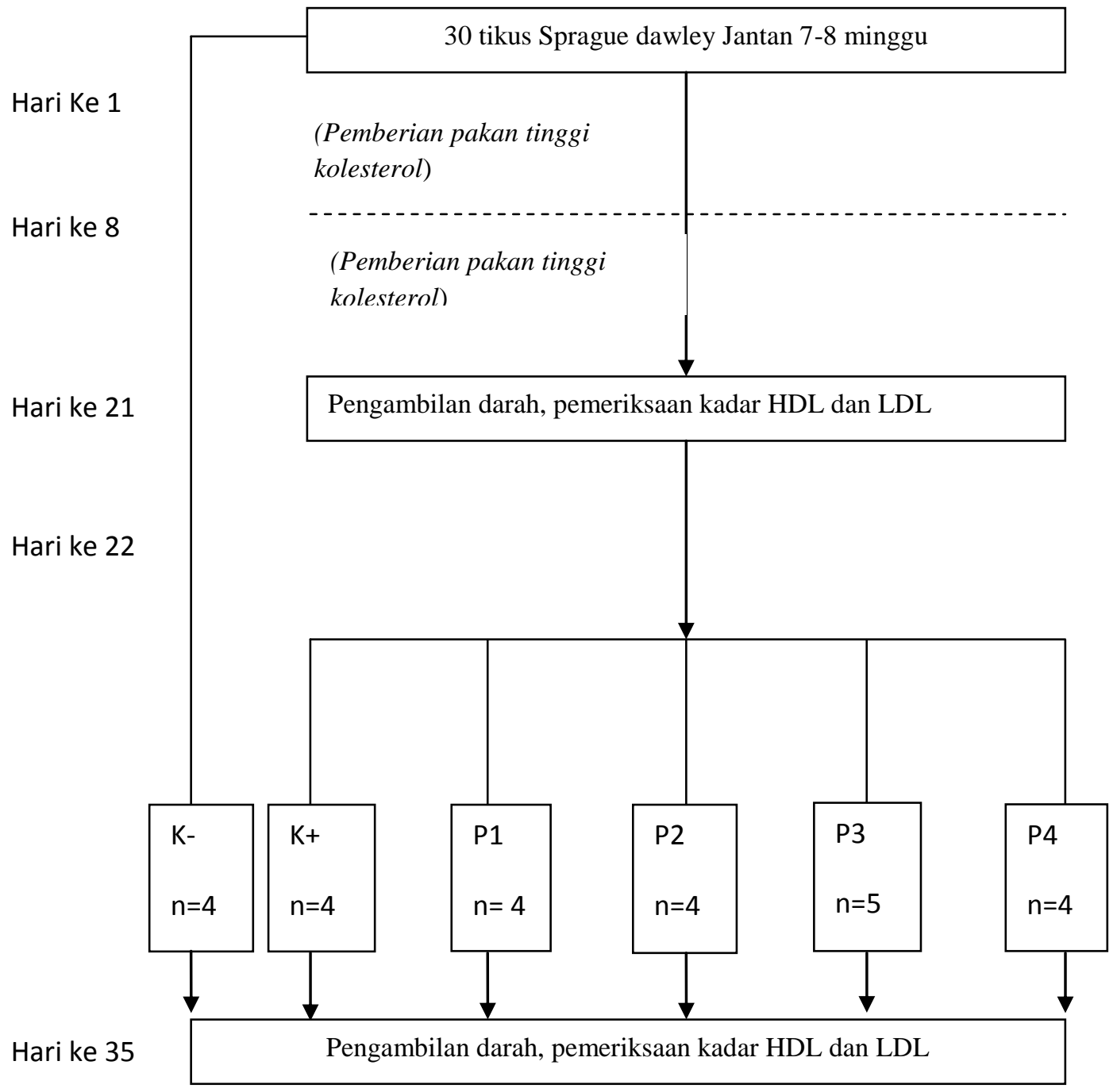




\section{HASIL PENELITIAN}

\section{Karakteristik Sampel}

Tiga puluh tikus Sprague dawley berjenis kelamin jantan usia 8 minggu dengan berat berkisar antara 150-200 gram dipelihara dalam kandang individu dengan suhu $28-32^{\circ} \mathrm{C}$ dan siklus pencahayaan 12 jam.Terdapat lima ekor tikus mati pada masing-masing kelompok kecuali pada kelompok perlakuan 3 (P3) pada minggu pertama dan minggu ketiga sehingga jumlah sampel menjadi 25 ekor.

Pertumbuhan berat badan tikus dipantau dengan penimbangan yang dilakukan setiap mingg. Penimbangan sisa pakan dilakukan setiap hari untuk mengetahui asupan pakan setiap harinya. Berat badan dan asupan pakan dapat dilihat pada tabel 1 dan 2.

Tabel 1. Hasil Analisis Berat Badan Tikus Sebelum dan Selama Perlakuan

\begin{tabular}{|c|c|c|c|c|c|}
\hline \multirow[t]{2}{*}{ Kelompok } & \multirow[t]{2}{*}{$\mathbf{N}$} & \multicolumn{2}{|c|}{ Rerata \pm SD (unit) } & \multirow[t]{2}{*}{$\Delta$} & \multirow[t]{2}{*}{$\mathbf{p}$} \\
\hline & & Sebelum (g) & Selama $(g)$ & & \\
\hline K- & 4 & $176,1 \pm 10.09^{\mathrm{a}}$ & $219,6 \pm 18,94^{b}$ & $43,5 \pm 2,37 a$ & $0,035^{\mathrm{c}} *$ \\
\hline $\mathrm{K}+$ & 4 & $182,0 \pm 7,96^{\mathrm{a}}$ & $215,6 \pm 16.8^{b}$ & $33,6 \pm 9,39$ & $0,336^{\mathrm{c}}$ \\
\hline P1(apel+kulit) & 4 & $162,4 \pm 20.76^{\mathrm{a}}$ & $194,0 \pm 28,15^{b}$ & $31,6 \pm 10,7$ & $0,010^{\mathrm{c}} *$ \\
\hline P2(apel) & 4 & $178,9 \pm 4,97^{\mathrm{a}}$ & $209,8 \pm 6,65^{b}$ & $30,9 \pm 9,71$ & $0,008^{\mathrm{c}} *$ \\
\hline P3(apel+kulit+susu) & 5 & $181,6 \pm 8,18^{\mathrm{a}}$ & $218,9 \pm 17,2^{b}$ & & $0,043^{\mathrm{c}} *$ \\
\hline P4(apel+susu) & 4 & $179,8 \pm 9,26^{\mathrm{a}}$ & $212,8 \pm 9,91^{\mathrm{b}}$ & $\begin{array}{c}37,3 \pm 24,75 \\
33,0 \pm 3,44\end{array}$ & $0,000^{\mathcal{C} *}$ \\
\hline
\end{tabular}

${ }^{\mathrm{a}}$ Uji Kruskall Wallis ${ }^{\mathrm{b}}$ Uji One Way Anova ${ }^{\mathrm{c}}$ Paired t-test $*$ berbeda/bermakna $(\mathrm{p}<0,05)$

Hasil analisis menunjukkan bahwa terdapat perbedaan yang bermakna $(p<0,05)$ antara berat badan sebelum dan berat badan setelah perlakuan pada semua kelompok kecuali kelompok $\mathrm{K}+(p>0,05)$. Berdasarkan uji Kruskall Wallis pada berat badan sebelum perlakuan menunjukkan bahwa tidak ada perbedaan berat badan antara keenam kelompok $(p=0,353)$ dan uji One Way Anova pada berat badan selama perlakuan menunjukkan bahwa tidak ada perbedaan berat badan antara keenam kelompok $(p=0,353)$.

Tabel 2. Hasil Analisis Asupan Pakan Tikus Sebelum dan Selama Perlakuan

\begin{tabular}{llllll}
\hline Kelompok & N & \multicolumn{2}{c}{ Rerata \pm SD (unit) } & $\Delta$ & $\boldsymbol{P}$ \\
\cline { 2 - 4 } & & Sebelum $(\mathbf{g})$ & Selama $(\mathbf{g})$ & & \\
\hline K- & 4 & $19,1 \pm 0,20^{\mathrm{a}}$ & $19,2 \pm 0,19^{\mathrm{a}}$ & $0,1 \pm 0,17$ & $0,388^{\mathrm{b}}$ \\
K+ & 4 & $18,5 \pm 0,35^{\mathrm{a}}$ & $19,0 \pm 0,07^{\mathrm{a}}$ & $0,5 \pm 0,39$ & $0,089^{\mathrm{b}}$ \\
P1(apel+kulit) & 4 & $19,0 \pm 0,14^{\mathrm{a}}$ & $19,0 \pm 0,07^{\mathrm{a}}$ & $-0,0 \pm 0,18$ & $0,987^{\mathrm{b}}$ \\
P2(apel) & 4 & $19,2 \pm 0,25^{\mathrm{a}}$ & $19,1 \pm 0,09^{\mathrm{a}}$ & $-0,1 \pm 0,20$ & $0,432^{\mathrm{b}}$ \\
P3(apel+kulit+susu) & 5 & $18,7 \pm 0,41^{\mathrm{a}}$ & $17,4 \pm 0,16^{\mathrm{a}}$ & $-1,3 \pm 0,36$ & $0,001^{\mathrm{b}} *$ \\
P4(apel+susu) & 4 & $18,5 \pm 0,44^{\mathrm{a}}$ & $17,3 \pm 0,26^{\mathrm{a}}$ & $-1,2 \pm 0,47$ & $0,013^{\mathrm{b}}{ }^{\mathrm{a}}$ \\
\hline
\end{tabular}

${ }^{\mathrm{a}} \mathrm{Uji}$ One Way Anova ${ }^{\mathrm{b}}$ Uji Paired t-test *berbeda/bermakna $(\mathrm{p}<0,05)$

Bedasarkan data yang ditunjukkan dari tabel 2, didapatkan hasil bahwa terdapat perbedaan yang bermakna $(p<0,05)$ antara asupan pakan sebelum dan selama perlakuan pada kelompok P3 dan kelompok P4. Selisih asupan pakan sebelum dan sesudah paling tinggi terdapat pada kelompok
P3yaitu 1,32 gram dan paling rendah pada kelompok P1 yaitu 0,00 gram.

Analisis Kadar Kolesterol LDL dan HDL

Pemeriksaan kadar kolesterol LDL dan HDL dilakukan pada sebelum dan setelah perlakuan. Gambaran rerata kadar kolesterol LDL dan HDLyang ditampilkan pada tabel 3 dan 4.

Tabel 3. Hasil Analisis Kadar Kolesterol LDL Sebelum dan Sesudah Perlakuan

\begin{tabular}{llcccc}
\hline Kelompok & $\mathbf{N}$ & \multicolumn{2}{c}{ Rerata \pm SD (unit) } & $\Delta$ & $\boldsymbol{P}$ \\
\cline { 2 - 4 } & & $\begin{array}{l}\text { Sebelum } \\
(\mathbf{m g} / \mathbf{d l})\end{array}$ & Sesudah $(\mathbf{m g} / \mathbf{d l})$ & & \\
\hline $\mathrm{K}-$ & 4 & $24,0 \pm 0,58^{\mathrm{a}}$ & $27,8 \pm 7,71^{\mathrm{a}}$ & $3,8 \pm 4,57$ & $0,200^{\mathrm{b}}$ \\
\hline
\end{tabular}




\begin{tabular}{lccccc}
\hline K+ & 4 & $19,5 \pm 1,91^{\mathrm{a}}$ & $22,0 \pm 3,83^{\mathrm{a}}$ & $2,5 \pm 4,12$ & $0,312^{\mathrm{b}}$ \\
P1(apel+kulit) & 4 & $27,0 \pm 6,58^{\mathrm{a}}$ & $25,8 \pm 3,20^{\mathrm{a}}$ & $-1,2 \pm 8,88$ & $0,797^{\mathrm{b}}$ \\
P2(apel) & 4 & $25,0 \pm 4,16^{\mathrm{a}}$ & $30,8 \pm 4,99^{\mathrm{a}}$ & $5,8 \pm 6,94$ & $0,196^{\mathrm{b}}$ \\
P3(apel+kulit+ & 5 & $24,4 \pm 4,61^{\mathrm{a}}$ & $20,8 \pm 1,92^{\mathrm{a}}$ & $-3,6 \pm 3,84$ & $0,105^{\mathrm{b}}$ \\
susu) & & & & \\
P4(apel+susu) & 4 & $22,8 \pm 3,30^{\mathrm{a}}$ & $24,8 \pm 4,99^{\mathrm{a}}$ & $2,0 \pm 5,09$ & $0,490^{\mathrm{b}}$ \\
\hline
\end{tabular}

${ }^{\mathrm{a}}$ Uji One Way Anova. ${ }^{\mathrm{b}} \mathrm{Uji}$ Paired t-test

Hasil analisis menunjukkan adanya penurunan kadar kolesterol LDL pada kelompok perlakuanjus apel dengan kulit dan kelompok perlakuan jus apel dengan kulit dan susu tinggi kalsium rendah lemak. Tidak terdapat penurunan kadar kolesterol LDL secara bermakna terdapat pada semua kelompok. Penurunan tertinggi terjadi pada kelompok P3 yaitu 3,60mg/dl.Berdasarkan, uji One Way Anova menunjukkan bahwa tidak terdapat perbedaan kadar kolesterol LDL antara keenam kelompok $(p>0,05)$

Tabel 4. Hasil Analisis Kadar Kolesterol HDL Sebelum dan Sesudah Perlakuan

\begin{tabular}{lccccc}
\hline Kelompok & $\mathbf{N}$ & \multicolumn{2}{c}{ Rerata \pm SD (unit) } & $\Delta$ & $\boldsymbol{P}$ \\
\cline { 3 - 4 } & & $\begin{array}{l}\text { Sebelum } \\
(\mathbf{m g} / \mathbf{d l})\end{array}$ & \multicolumn{1}{c}{ Sesudah (mg/dl) } & & \\
\hline K- & 4 & $19,2 \pm 2,21^{\mathrm{a}}$ & $20,0 \pm 2,16^{\mathrm{a}}$ & $0,8 \pm 2,62$ & $0,608^{\mathrm{b}}$ \\
K+ & 4 & $17,7 \pm 1,25^{\mathrm{a}}$ & $15,5 \pm 2,88^{\mathrm{a}}$ & $-2,2 \pm 2,21$ & $0,135^{\mathrm{b}}$ \\
P1(apel+kulit) & 4 & $19,0 \pm 2,16^{\mathrm{a}}$ & $18,0 \pm 1,41^{\mathrm{a}}$ & $-1,0 \pm 1,63$ & $0,308^{\mathrm{b}}$ \\
P2(apel) & 4 & $21,7 \pm 2,50^{\mathrm{a}}$ & $17,5 \pm 3,87^{\mathrm{a}}$ & $-4,2 \pm 5,05$ & $0,191^{\mathrm{b}}$ \\
P3(apel+kulit+ & 5 & $18,6 \pm 1,51^{\mathrm{a}}$ & $16,8 \pm 2,94^{\mathrm{a}}$ & $-1,8 \pm 2,77$ & $0,221^{\mathrm{b}}$ \\
susu) & & & & & \\
P4(apel+susu) & 4 & $18,0 \pm 4,83^{\mathrm{a}}$ & $18,0 \pm 2,16^{\mathrm{a}}$ & $0,0 \pm 2,82$ & $1,000^{\mathrm{b}}$ \\
\hline
\end{tabular}

${ }^{\mathrm{a}}$ Uji One Way Anova ${ }^{\mathrm{b}}$ Uji Paired t-test

Hasil analisis menunjukkan tidak ada perubahan kadar kolesterol HDL pada keenam kelompok yaitu kelompok K-, kelompok $\mathrm{K}+$, kelompok P1, kelompok P2, kelompok P3, kelompok
P4.Berdasarkan uji One Way Anova menunjukkan bahwa tidak ada perbedaan kadar kolesterol HDL antara keenam kelompok $(p>0,05)$

Tabel 5. Perbedaan Perubahan Asupan Pakan, Berat Badan, Kadar Kolesterol HDL dan LDL pada Enam Kelompok Perlakuan.

\begin{tabular}{|c|c|c|c|c|c|c|c|}
\hline Rerata & K- & $\mathbf{K}+$ & P1 & $\mathbf{P 2}$ & $\mathbf{P 3}$ & P4 & $P$ \\
\hline $\begin{array}{l}\Delta \text { Asupan } \\
\text { pakan }\end{array}$ & $0,08 \mathrm{~g}$ & $0,49 \mathrm{~g}$ & $0,00 \mathrm{~g}$ & $-0,09 \mathrm{~g}$ & $-1,32 \mathrm{~g}$ & $-1,26 \mathrm{~g}$ & $0,002 *$ \\
\hline $\begin{array}{l}\Delta \text { Berat } \\
\text { Badan }\end{array}$ & $343,52 \mathrm{~g}$ & $33,58 \mathrm{~g}$ & $31,58 \mathrm{~g}$ & $30,82 \mathrm{~g}$ & $37,40 \mathrm{~g}$ & $33,01 \mathrm{~g}$ & 0,976 \\
\hline $\begin{array}{l}\Delta \text { Kadar } \\
\text { HDL }\end{array}$ & $0,75 \mathrm{mg} / \mathrm{dl}$ & $\begin{array}{c}- \\
2,25 \mathrm{mg} / \mathrm{dl}\end{array}$ & $\begin{array}{c}- \\
1,00 \mathrm{mg} / \mathrm{dl}\end{array}$ & $\begin{array}{l}-4,25 \\
\mathrm{mg} / \mathrm{dl}\end{array}$ & $\begin{array}{l}-1,80 \\
\mathrm{mg} / \mathrm{dl}\end{array}$ & $\begin{array}{c}0,0 \\
\mathrm{mg} / \mathrm{dl}\end{array}$ & 0,279 \\
\hline $\begin{array}{l}\Delta \text { Kadar } \\
\text { LDL }\end{array}$ & $3,75 \mathrm{mg} / \mathrm{dl}$ & $2,50 \mathrm{mg} / \mathrm{dl}$ & $\begin{array}{l}-1,25 \\
\mathrm{mg} / \mathrm{dl}\end{array}$ & $\begin{array}{c}5,75 \\
\mathrm{mg} / \mathrm{dl} \\
\end{array}$ & $\begin{array}{l}-3,60 \\
\mathrm{mg} / \mathrm{dl}\end{array}$ & $\begin{array}{c}2,00 \\
\mathrm{mg} / \mathrm{dl}\end{array}$ & 0,224 \\
\hline
\end{tabular}

Uji post hoc: $\mathrm{K}$ - vs P3 $p=0,014, \mathrm{~K}$-vs $\mathrm{P} 4 p_{=} 0,021, \mathrm{~K}+\mathrm{vsP} 3 p=0,14, \mathrm{~K}+\mathrm{vsP} 4 p=0,29, \mathrm{P} 1$ vs $\mathrm{P} 3 p=0,14, \mathrm{P} 1$ vs $\mathrm{P} 4 p=0,021, \mathrm{P} 2$ vs $\mathrm{P} 3 p=0,14, \mathrm{P} 2$ vs $\mathrm{P} 4 p=0,029$

Hasil analisis uji One Way Anoval uji Kruskall Wallis , diketahui berat badan, kadar HDL dan kadar LDL mempunyai nilai $p>0,05$. Hal ini menunjukkan bahwa tidak terdapat perbedaan pengaruh kadar HDl, kadal LDL dan berat badan secara bermakna pada keenam kelompok, sedangkan pada asupan pakan terdapat perbedaan pengaruh secara bermakna pada keenam kelompok $(p<0,001)$. 


\section{PEMBAHASAN}

\section{Berat badan Subjek dan Asupan Pakan}

Penimbangan berat badan tikus dan sisa pakan dilakukan setiap hari.Dari hasil pengukuran berat badan menunjukkan bahwa tidak terdapat perbedaan berat badan sebelum dan selama perlakuanantar kelompok. Berat badan sebelum dan sesudah perlakuan mengalami peningkatan yang secara statistik bermakna kecuali pada kelompok kontrol positif secara statisitik tidak bermakna. Peningkatan berat badan yang paling tinggi terdapat pada kelompok kontrol negatif yaitu $176,14 \mathrm{~g}$ menjadi $219,66 \mathrm{~g}$. Hal tersebut terjadi karena kelompok kontrol negatif diberi pakan standar dengan jumlah yang sama dengan seluruh sampel yaitu sebesar 20 gram,namun tidak adanya faktor stress pada kelompok kontrol negatifmenyebabkan berat badan terus bertambah Pada hasil analisis asupa pakan menunjukkan kelompok P3 dan P4 mengalami penurunan asupan makanan secara bermakna. Hal ini dikarenakan pemberian susu sebanyak $6,16 \mathrm{ml}$ sehingga asupan pakan standar menurun.

\section{Pemberian Pakan Tinggi Kolesterol}

Pada penelitian ini untuk menginduksi hiperkolesterolemia pada tikus digunakan pakan tinggi kolesterol, yaitu pakan yang terdiri dari pakan standar ditambahkan otak sapi $10 \%$ dari jumlah pakan standar. Otak sapi dipilih karena mengandung kolesterol tinggi yaitu 2000mg per $100 \mathrm{~g} .{ }^{14}$ Keadaan hiperkolesterolemia diketahui dengan cara membandingkan kadar kolesterol HDL dan kolesterol LDL tikus yang mendapat pakan tinggi kolesterol (kontrol positif, perlakuan pemberian jus apel dengan kulit, jus apel tanpa kulit, jus apel dengan kulit + susu tinggi kalsium rendah lemak, dan jus apel tanpa kulit + susu tinggi kalsium rendah lemak ) dengan kelompok kontrol negatif.

Hasil analisis menunjukkan bahwa tidak terdapat perbedaan kolesterol HDL yang bermakna antar kelompok setelah pemberian pakan tinggi kolesterol. Namun secara deskriptif, kelompok kontrol negatif memiliki kadar kolesterol HDL paling tinggi dibandingkan dengan kelompok lain.Hal tersebut bisa dikarenakan kelompok kontrol negatif hanya mendapat pakan standar yang tidak ditambah dengan otak sapi. Kadar kolesterol LDL antar kelompok setelah pemberian pakan tinggi kolesterol tidak menunjukkan perbedaan yang bermakna. Kelompok perlakuan jus apel tanpa kulit memiliki rerata kadar kolesterol LDL yang paling tinggi dibandingkan dengan kelompok lain, diikuti dengan kelompok kontrol negatif, kelompok perlakuan jus apel + kulit, kelompok perlakuan jus apel tanpa kulit+ susu tinggi kalsium rendah lemak,kelompok kontrol positif dan kelompok jus apel denga kulit+ susu tinggi kalsium rendah lemak. Hal tersebut bisa dikarenakan karena dilihat dari asupan makan kelompok P2 tergolong tinggi.

Tingginya kadar kolesterol LDL kelompok kontrol negatif dapat dipengaruhi oleh faktor berat badan selama perlakuan yang memiliki rerata paling tinggi dibandingkan dengan kelompok lain. Berat badan yang berlebih akan meningkatkan produksi lipoprotein yang mengandung LDL sehingga kadar kolesterol LDL menjadi tinggi. ${ }^{15}$

\section{Pengaruh Jus Apel Fuji dan Susu Tinggi Kalsium Rendah Lemak terhadap Kadar Kolesterol LDL}

Pada penelitian ini,kadar LDL sebelum dan setelah perlakuan tidak menunjukkan perbedaan antar kelompok . Hasil analisis menunjukkan bahwa pada kelompok perlakuan jus apel fuji dengan kulit dan jus apel fuji dengan kulit+ susu tinggi kalsium rendah lemak mengalami penurunan secara berturut-turut dari 27 $\mathrm{mg} / \mathrm{dl}$ menjadi $25,75 \mathrm{mg} / \mathrm{dl}$ dan dari $24,40 \mathrm{mg} / \mathrm{dl}$ menjadi $20,80 \mathrm{mg} / \mathrm{dl}$, namun penurunan tersebut secara statistik tidak bermakna yaitu $(p=0,797)$ dan $(p=0,105)$. Kelompok kontrol dan perlakuan lainnya mengalami peningkatan namun tidak bermakna.

Penurunan rasio kolesterol pada kelompok perlakuan jus apel fuji dengan kulit dan jus apel fuji dengan kulit ditambah susu tinggi kalsium rendah lemak disebabkan adanya zat fitokimia berupa flavonoid yaitu quercetin dan cathecin dalam kulit apel. Mekanisme penurunan rasio kolesterol LDL oleh flavonoid melalui beberapa faktor yaitu peningkatan ekskresi empedu dan penghambatan absorbsi kolesterol . Flavonoid dapat bertindak sebagai kofaktor enzim kolesterol esterase dan penghambat absorbs kolesterol makanan melalui penghambatan pembentukan misel sehingga kolesterol mengendap dan penyerapannya dapat ditekan. ${ }^{16,17}$ Selain flavonoid , kulit pada buah apel fuji mengandung serat larut air yaitu pektin. Pektin memiliki mekanisme hipolipidemia,di dalam saluran pencernaan, serat larut air mengikat asam empedu yang merupakan produk akhir dari kolesterol dan kemudian dikeluarkan bersama feses, hal ini yang dapat menurunkan kadar kolesterol tubuh. Mekanisme kerja kalsium berhubungan dengan peran intraseluler kalsium dalam metabolisme pada jaringan. Adanya peningkatan konsumsi kalsium 
dalam bahan pangan akan menurunkan konsentrasi 1,25- dehidroksi vitamin D3 (1,25 (OH2) D3). Hasilnya akan menyebabkan penurunan pengaturan transfer kalsium ke adiposa dan pankreas. Pada adiposa penurunan konsentrasi kalsium intraseluler akan menurunkan enzim asam lemak sintase, penurunan proses lipogenesis, dan peningkatan lipolisis. Pada sel pankreas, penurunan konsentrasi kalsium dalam intraseluler akan menurunkan produksi insulin yang akan berpengaruh terhadap penurunan lipogenesis dan peningkatan lipolisis dalam adiposit. Kombinasi kedua ini berperan dalam penurunan simpanan lemak dalam jaringan adiposa. ${ }^{18,19}$

Pada kelompok kontrol negatif, peningkatan kadar kolesterol LDL dapat dipengaruhi oleh bertambahnya umur dan berat badan sampel, dilihat dari tabel 1 rerata berat badan kelompok negatif paling tinggi. Kelompok kontrol positif mengalami peningkatan kadar LDL selain di karenakan bertambahnya umur dan berat badan juga dipengaruhi oleh asupan makanan tinggi kolesterol yang dikonsumsi, sedangkan pada kelompok jus apel fuji tanpa kulit dan jus apel fuji tanpa kulit + susu tinggi kalsium rendah lemak mengalami peningkatan kadar LDL bisa dikarenakan adanya proses browning pada jus apel. Pada proses browning total asam akan mengalami penurunan hal ini dapat mengakibatkan jumlah vitamin $\mathrm{C}$ pada apel mengalami penurunan, dikarenakan vitamin $\mathrm{C}$ mudah rusak. ${ }^{14}$ Vitamin $\mathrm{C}$ merupakan zat antioksidan yang kuat untuk menurunkan kadar LDL. Pada kelompok perlakuan jus apel fuji dengan kulit dan perlakuan jus apel fuji dengan kulit + susu tinggi kalsium rendah lemak juga mengalami proses browning namun zat antioksidan yang terdapat pada kulit lebih besar daripada pada daging buah dan adanya serat larut air yang terkandung didalamnya sehingga kadar LDL dapat menurun.

\section{Pengaruh Jus Apel Fuji dan Susu Tinggi Kalsium Rendah Lemak terhadap Kadar Kolesterol HDL}

Jus apel fuji dan susu tinggi kalsium rendah lemak diharapkan mampu menaikan kadar koleterol HDL. Pada penelitian ini menunjukkan kadar kolesterol HDL pada seluruh kelompok sebelum dan setelah intervensi mengalami penurunan, kecuali kelompok kontrol negatif. Secara statistik, kelompok control dan perlakuan mengalami perubahan yang tidak bermakna. Secara deskriptif, kelompok yang mengalami peningkatan kolesterol HDL adalah kelompok kontrol negatif. Hal ini dapat dikarenakan kelompok ini tidak mendapat asupan pakan tinggi kolesterol,disamping itu pada kelompok ini tidak mendapat asupan pakan dengan menggunakan alat sonde sehingga faktor stress dapat ditekan. Kelompok kontrol positif dan semua kelompok perlakuan mengalami penurunan kadar HDL disebabkan karena asupan makanan tinggi kolesterol yang dikonsumsi, disamping itu terjadinya proses browning pada jus apel memungkinkan terjadi penurunan jumlah zat anti oksidan dalam jus apel.

\section{KETERBATASAN PENELITIAN}

Keterbatasan penelitian ini adalahtidak dilakukan pengujian terhadap kandungan flavonoid dan serat pangan yang terdapat pada jus apel sehingga tidak dapat diketahui seberapa besar peran flavonoid dan serat larut air terhadap perubahan kadar kolesterol LDL dan kolesterol HDL serta belum berhasilnya membuat hiperkolesterolemia pada tikus.

\section{SIMPULAN}

Pemberian jus apel dengan kulit, jus apel, jus apel dengan kulit dan susu tinggi kalsium rendah lemak serta jus apel dan susu tinggi kalsium rendah lemak selama 14 hari tidak berpengaruh terhadap kadar kolesterol LDL dan kolesterol HDL darah pada tikus hiperkolesterolemia .

\section{SARAN}

Perlu penelitian lebih lanjut mengenai pengaruh pemberian jus apel fuji dan susu tinggi kalsium rendah lemak terhadap kadar kolesterol LDL dan HDL darah dengan melakukan uji terhadap kandungan flavonoid dan serat pangan pada jus apel fuji dan kandungan kalsium beserta lemak pada susu tinggi kalsium rendah lemak.

\section{UCAPAN TERIMA KASIH}

Puji syukur penulis panjatkan ke hadirat Tuhan Yang Maha Esa atas kemudahan dan kelancaran yang telah diberikan-Nya. Terima kasih kepada Prof.dr.M.Sulchan,M.Sc,Da.Nutr,Sp.GK selaku pembimbing dan para reviewer yang telah membimbing penelitian ini hingga dapat terlaksana sampai akhir.Ucapan terima kasih juga disampaikan kepada keluarga dan teman-teman atas dukungan yang telah diberikan selama penelitian ini berlangsung.

\section{DAFTAR PUSTAKA}

1. World Health Organization,WHO Report 2011, Geneva: WHO,2011 
2. Adam JM, Soegondo S, Semiardji G, Ardiansyah H. Petunjuk Praktis Penatalaksanaan Dislipidemia.Jakarta:PB.PERKENI:2004:1-22

3. Jeanelle Boyer dan Rui Hai Liu. Apple phytochemical and their benefits.Nutrition Jurnal 2004

4. Sareen S. Gropper, Jack L. Smith, James L. Groof. Advanced Nutrition and Human Metabolism $5^{\text {th }}$ edition.USA:Wadsworth.;2009. Hal :110

5. Sabine Sembries, Gerhard Dongowski, Katri Mehrlander, Frank Will, Helmut Dietrich. Dietary fiber- rich colloid from apple pomace extraction juice do not affect food intake and blood serum lipid levels, but enhance fecal excretion of steroids in rats. Journal of Nutritional Biochemistry .2004;15; 296 302

6. Mahbubeh Setorki, Sedighe Asgary, Akram Eidi, Ali Haeri Rohani et al. Effect of apple juice on risk factors of lipid profile, inflammation and coagulation, endothelial markers and atherosclerositic lesions in high cholesterolemic rabbit. Lipid in Health and Disease 2009,8:39

7. Zemel,MB. Role of calcium and diary product in energy partitioning ang weight management. Am J Clin Nutr 2004;79(suppl):907S-12S.

8. Zemel, MB et al. 2004.Calcium and Dairy Acceleration of Weight andFat Loss during Energy Restriction in Obese Adults. Obesity Research vol 12 No 4 April 2004

9. Schrager Sarina. 2005.Dietary Calcium Intake and Obesity. J Am Board Fam Pract 2005;18:205-10

10. Supranto J. Teknik Sampling untuk Survei dan Eksperimen. Jakarta: Penerbit PT Rineka Cipta; 2000.

11. Astirani AE, Muwarni H. Pengaruh Pemberian SARI Daun Cincau (Premna oblongifolia Merr) terhadap Kadar Kolesterol HDL dan Kolesterol LDL Tikus Sprague Dawley Dislipidemia. Semarang: Universitas Diponegoro; 2012.

12. Sharp PE, Regina MCL. The Laboratory Rat. USA: CRC Press LLC; 1998

13. Dahlan MS. Statistik untuk Kedokteran dan Kesehata. Jakarta: Salemba Medika; 2011

14. Winarno FG.Kimia Pangan dan Gizi.Jakarta: PT Gramedia Pustaka Utama:2004

15. Hoenig MR. Low Density Lipoprotein cholesterol is Inversely Correlated with Abdominal Visceral Fat Area. Biomed Central ; 2011. 10:12

16. Olivera T, Ricardo KFS, Almeida MR, Costa MR, Nagem TJ. Hypolipidemic Effect of Flavonoids and Cholestyramine in Rats Tania. Latin American Journal of Pharmacy 2007; 26 (3): 407-10.

17. Gropper SS, Smith JL, Groff JL. Advanced Nutrition and Human MetabolismFifth Edition. USA : Wadsworth, Cengage Learning. 2009; 131-75.

18. Hansel Boris, Nicolle Catherine, Lalane Florent. Effect of low-fat, fermented milk enriched with plant sterols on serum lipid profile and oxidative stress in moderate Hypercholesterolemia. Am J Clin Nutr 2007;86:790-6.

19. Venti CA, Tatarani PA, Salbe AD. Lack of Relationship between Calcium Intake and Body Size in an Obesity-Prone Population . J Am Diet Assoc. 2005;105:1401-140 